\title{
LOCUS STANDI, A COMMENTARY ON THE LAW OF STANDING IN CANADA
}

By Thomas A. Cromwell, Carswell Co. Ltd., 1986

In his preface, Professor Cromwell tells us that his aim in writing this book ". . . is to be the most comprehensive Canadian treatment of the subject to date". However, as he observes, the comprehensiveness of the text has to be limited by the vast subject matter with which Professor Cromwell must deal. Therefore, he confines himself to look at the question only from the plaintiff's perspective and limits himself for the most part, to the common law provinces of Canada.

Whether a person has standing to sue in any given circumstance can sometimes be very difficult to answer. This is not helped by the fact that different rules apply depending on the substantive law involved and the remedy being sought. Professor Cromwell has a difficult task to meld the decisions of the Courts of Appeal across the country into a consensus on the law of standing. It is unlikely that the Supreme Court of Canada will provide leadership in this area, given that court's present preoccupation with Charter cases, and it may be that is it impossible to arrive at one law of standing which is current across the country. Nevertheless, this text on this subject matter is welcome.

In exploring what the Canadian Courts have said about this question, Professor Cromwell has propounded a theoretical framework which he hopes might guide the future development of the law.

Professor Cromwell provides a working definition of standing which he uses in his book. For his purposes, the term 'standing' ". . . means entitlement to seek judicial relief apart from questions of the substantive merits and the legal capacity of the plaintiff:' In his Introduction, he describes the other definitions which have been used but justifies his rejection of them in favour of his own.

He thus resists the common approach of classifying the interest which a plaintiff might have in order to determine whether that plaintiff might be given standing. This is despite the fact that this has been the approach that the Courts have used for the most part. He does this for two reasons. First, the Supreme Court of Canada has given a lead in the case of Thorson v. Attorney General of Canada. Professor Cromwell argues that the Supreme Court has abandoned the link between standing and the interest of the plaintiff and has adopted instead another consideration defined by the phrase "justiciability of the question and the availability of alternative means of securing judicial intervention". The correct view of the Supreme Court of Canada's decision is still in debate but at least the narrow consideration of the plaintiff's kind of interest alone is not enough. Secondly, Professor Cromwell believes that from a consideration of principle, a test for standing based on the plaintiff's interest is " . . . at best uninformative and at worst conclusory".

However, his definition has its own limitations since it is sometimes impossible to draw the distinction between standing and the substantive merits of the case and, secondly, between standing and the capacity to sue. Where the issues are interrelated, Professor Cromwell's definition cannot stand on its own. 
Chapter 2 describes the sources of the standing doctrine in four substantive areas of the law. The first is the right of an individual to sue in Public Nuisance. This area was chosen because it has provided most of the standing rules in public law. The second is Shareholders' Actions and the standing of a shareholder to sue for corporate wrongs. Since judicial pronouncements in the corporate area were subsequently used for guidance in determining whether a ratepayer had standing to sue in the Municipal Law area, the latter is therefore the third substantive area considered. Fourthly, Professor Cromwell discusses the standing of an individual to seek a declaration concerning the constitutionality of legislation. He sees ". . . a rough, but clearly discernible, continuum from company law cases ... through ratepayer's cases . . . up to the landmark decision in Thorson." This continuum is his justification for choosing these particular areas of substantive law.

Chapter 3 discusses the rules of standing from the point of view of remedies. The remedies dealt with are certiorari, mandamus, prohibition, declaration and injunction. It is in these areas that the law of standing has its most practical application and it is in these cases also that there is the most material. The chapter on remedies concludes with statutory remedies as alternative means of obtaining judicial review and the rules of standing contained in certain statutes - the Judicial Review Procedure Acts of British Columbia and Ontario and the Federal Court Act.

Professor Cromwell has chosen to combine these two approaches because each alone has its drawbacks and in this way he hopes to avoid the limitations of either approach used singly. Whether a remedy is available depends sometimes on the substantive law context in which it is sought; for example, declarations and injunctions. However, if one were to concentrate on the substantive law context alone, the chapters would be endless.

In his last two chapters, Professor Cromwell attempts to examine critically the rules and their rationale to seek a synthesis and puts forward some suggestions for reform.

The discussion of the law of standing in the four substantive areas and through the remedies is a useful precis of the present state of uncertainty, one might even say confusion, in the courts. From this he draws three general principles:

(a) normally the plaintiff must have sufficient "interest" in the subject matter of the suit;

(b) the private plaintiff ought to have unrestricted access to the courts only with respect to matters involving his own private rights, as opposed to public rights, and matters in which he can show some special interest;

(c) it is appropriate for the Attorney General to play a role in deciding which cases affecting public rights may be decided by the courts.

Professor Cromwell then goes on to examine whether these principles are appropriate from the point of view of the reasons usually given for requiring a standing doctrine at all. These reasons themselves are also scrutinized to determine their validity. He concludes that there should be judicial control over the issue of standing but not a generalized bar. He advocates increased judicial discretion to determine the issue (such as was 
apparent in Thorson) because

(T)he creation of a discretion acknowledges the obvious point that it is difficult to enunciate a fixed test for standing that is capable of reasonably precise application and yet likely to yield satisfactory and consistent results. (p.212)

In this way a court could limit standing as the particular circumstances of the case required and in accordance with the accepted belief that access to the courts should be limited for some purposes. Despite appearances to the contrary, this would not make the law any less certain than it presently is since de facto the court's discretion already determines the issue. In advocating this discretionary approach, Professor Cromwell is disagreeing with other commentators in the Administrative Law field who object to a wholesale application of discretion. Professor Cromwell feels that the courts would exercise their discretion as equally to grant as well as to bar access in the proper case. In so doing the need to avoid a multiplicity of actions, the need to eliminate busybodies, and the need to ensure that only properly justiciable questions are presented for adjudication will be met.

Finally, Professor Cromwell provides a check list for judges to guide them in determing whether any given plaintiff has or should be given standing to proceed. The questions on the list cannot be answered on a theoretical basis, they can only be applied to the set of facts which are presented to the court in each case. After that, the judge is on his or her own. As an approach, it is a helpful way of dealing with the problem.

In conclusion, this is a useful book for litigants and scholars alike, and one hopes to see more scholarly work from Professor Cromwell in the future. 